\title{
Commentary: Cautionary Tales and Culture History in the Evolution of the Benin Kingdom: The Ogiso Era
}

\author{
Joseph Nevadomsky* \\ Department of Anthropology, California State University, USA
}

Submission: March 22, 2017; Published: June 15, 2017

*Corresponding author: Joseph Nevadomsky, Department of Anthropology, California State University, Fullerton, 800 N. State College Blvd., CA 92834, USA, Email: jnevadomsky@Exchange.FULLERTON.EDU

\section{We All Tilt at Windmills-Cervantes}

The prelude to the film version of Don Quixote opens with Don Manuel Cervantes jailed by the Inquisition for putting on charades. When inmates express amazement that anyone could be imprisoned for staging plays, someone replies that plays are not always what they seem. His fellow prisoners then put Cervantes on mock trial for being a poet. "Poets!" says one, "Spinning nonsense out of nothing! Blurring men's eyes to reality." Cervantes retorts: "Reality! A stone prison crushing the human spirit. Poetry demands imagination and with imagination you may discover a dream." His interlocutor replies: "I charge you with being an idealist, a bad poet and an honest man. How do you plead?" "Guilty," says Cervantes.

Understanding Benin kingdom history by professional historians and by the local Edo (Bini) are anchored to an authenticity in a traditional past, but these claims are like Cervantes mock trial: where does spinning nonsense out of nothing end and reality set in? Or is imagination as much a part of this record as the history itself? Are the Ogiso a part of the historical record or the creative fabrications of imaginative storytellers?

The former Benin Kingdom is known for its empire building in West Africa, its renowned copper-allow art, and its Guinness Book of World Record earth embankments. The people who inhabit that former kingdom, the Edo in Benin City and Edo State, in southern Nigeria, live in a cognitive world that, inter alia, includes a cosmological creation, a storybook dynasty of Ogiso, an Ife to Benin kingship connection, and a documented dynasty of kings, or oba.

This Ogiso pre-dynasty is what concerns me here. The Ogiso, roughly 900-1200 AD, ties into the kingship chronology of the 14th-20th centuries through the Ife-Benin hypothesis. This proto-historic Ogiso Era is widely used by historians and art historians as an acceptable springboard, a jumping off point, from which to study the brass and ivory art.
However, the Ogiso Era is problematic. It is farther back in time. It is opaque. Most historians view the Ogiso Era as a system of autonomous chieftaincy villages to state organization on a scale of political evolution. Ogiso means "sky kings" - a name that should raise some cautionary red flags.

Boilerplate texts takes the Ogiso as a "First Dynasty." Though this is a hazy period in Benin history, which the late Bradbury $[1,2]$ and some other scholars have dismissed as "mythical," local raconteurs and some other historians see the Ogiso as a dynasty of 34 Ogiso rulers like the 38 Oba of the 14 th-20th centuries. In these local constructions each Ogiso ruler is known for a singular contribution in this dynastic chronology. Eventually, as stories go, there was a succession conflict, necessitating a shift -the IfeBenin connection- that became the present Second Dynasty. I call it boilerplate because it is a generally accepted belief.

But can we accept this pre-dynastic boilerplate tradition in any literal sense? Like the mock trial of Cervantes, is the Ogiso history or poetry?

What sources of authority can we rely on in the understanding of this or any history? Mark [3] tells us, there are two kinds of history in the Marxist tradition. One is that of inevitability, an objective understanding of material conditions. This is realist history, factual and undistorted. Then there is the history of recitation, or vulgar history, an artifice of representation. This is the history of myth, of colloquialism and conventionality.

Can we separate the two? In History and Class Consciousness Lukacs [4] tells us that creating an objective past by use of a scientific method that can't relate itself to the present masks the vulgarization that accompanies any deliberate effort. Elizabeth Tonkin, in Narrating Our Pasts: The Social Construction of Oral History [5] says that the past is constrained by conventions of speech that introduce irony and manage contradictions. Lukacs and Tonkin challenge the orthodoxy of history as a transparent 
transmission of facts for which the historian sifts error from material reality. For the Marxist philosopher Lukacs and the British anthropologist Tonkin the task is to understand how history is written.

For Lukacs the past is vulgarization, for Tonkin semiotics, and for other commentators the past is a fabrication understood as elite ideologies [5], agency [6,7], memory as social practice [8], the social cognition of time [9], the political conditioning of narrative authority [10], discourse practices shaped by cultural expectations [11,12], systems of power/knowledge [13], dialogic folklore [14], and the social evolution of things [15].

Consider ca. 900-1200 AD, in Benin kingdom history where source materials are sparse. Oral narratives are clouded in myth, there are no external European accounts, artifacts are rare, and society as it is, is too far removed. Here we are investigating opaque spaces between narrative fiction and factual history. How can we navigate what Henige [16] calls "the unforgiving epistemology of deep-time oral tradition"? How can we avoid slipping, to paraphrase a statement in P. Bourdieu's [17] An Outline of Theory and Practice from the model of reality to the reality of the model? [18].

Not very well, I think. This slippage is occurring before our eyes. I argue that Benin kingdom's Ogiso Era is ossifying into fact -- rivets in the boilerplate - the creation of orthodoxy from fiction, aided and abetted by local raconteurs and professional historians. I offer three examples. One is fiction contrived as history and serves as a source for the other two examples. The second is history that credits fiction as a legitimate source. A third is fiction wedded to the Marxist tradition of state evolution.

The first example is Omorogie's [18,19] narratives compiled in Great Benin (1997-1999), and self-published separately beginning with The Age of Odionwere (600-900 AD) to The Age of Ogiso Foundation (900-1050 AD, The Age of Ogiso Reform (1050-1130 AD and The Age of Ikaladerhan (1130-1200 AD). Somewhere between mythic and make-believe recounting, there is no referencing, bibliography, source interviews, or historical methodology.

Omoregie initially said that he collected his information from the last surviving member of a guild of court recorders, the Ughoron. Before his death in 2015 Omoregie claimed his family was descended from the Ughoron and so he was exposed to the early history of Benin. Compiling these stories he reconstructed the Ogiso period of Benin history. One historian, Uyilaiva [20,21], writes that "ororegie's tenacity in researching an documenting this period filled a major hiatus in Jacob Egharevba's works" (2016:147) [22].

There is no oral or palace evidence for the existence of such a group. There is no family history of such an individual. Ughoron is an archaic term, literally "chamber of heaven," and refers to the ancestral realm (nowadays people use ẹrinmwin, "the spirit world"). Omorogie claims that the stories are legitimate history, that is, historical fact. Some basic fact-checking reveals that Omoregie must have been a young boy when he collected this information, a remarkable feat that fits in somewhere between the genie in a lamp or a note in a bottle found on a beach at Carmel. It is a narrative conceit professed by a self-actuated savant.

Although it reminds one of the Arthurian Legends, Omorogie's narratives are taken seriously. When the assertions are mythologies posed as historical facts that occurred in a "time long ago," the Edo public, like everyone else, relies on the authority of the teller. (The author has a doctorate degree in educational administration and served government in that capacity.) That such story telling is now be committed to print only exacerbates the problem of validity, and illumination, imposing a false sense of social and historical disambiguation.

The late Nigerian historian, Philip Igbafe whose 1979 study Benin Under Colonial Administration: The Impact of Colonial Rule on an African Kingdom 1897-1938 [23,24] extended Ryder's 1969 Benin and the Europeans 1485-1897 [25,26]. His writing on Benin's early history is methodologically careful but when he discusses the Ogiso era, he says there was once a guild of court recorders, the "Ughoron," and cites Omorogie as the source. As a result, other historians have cited it, and it is becoming codified in the study of Benin's prehistory.

Dmitri Bondarenko, a Moscow-based social anthropologist in the Russian Academy of Sciences Institute for African Studies, takes the Ogiso stories at face value, employing them to develop an evolutionary scheme for the early political development and incipient state centralization of pre-dynastic Benin. While most scholars accept the Ogiso a necessary precondition to state formation, Bondarenko accepts as credible the list of predynastic Ogiso, and for a reason: it works well with his Marxist reconstruction of evolutionary development. An elastic Marxistaligned structure serves as an excellent framework for an evolutionary schema resting upon the extended Omoregie mythohistory boilerplate. In a plethora of essays and publications on the Ogiso era he offers a chronological litany of early rulers, each accorded sophisticated achievements that advance the political and social agenda in lock step with evolutionary state formation theory, an approach reminiscent not only of Marx but other 19th century evolutionists and current adherents. There is an extraordinary convergence of mythic history and historical Marxism in Bonderanko's [27-31] work, especially in his Pre-Imperial Benin (2001), A Popular History of Benin: The Rise and Fall of a Mighty Forest Kingdom [32], and Homoarchy: A Principle of Culture's Organization (2006). His extensive list of publications is impressive, using state formation emergence theory as a baseline upon which has been overlaid a narrative history of pre-dynastic Benin [33]. 
It is the ultimate mantra, magical sky kings endowed with evolutionary political genes invested in a first dynasty of an evolving social order passed to a second dynasty of perpetual hierarchical reckonings. Lukasc somewhere makes the point that fitting together disparate elements into a coherent scheme within an historical paradigm is meaningless not because the elements of local expression and proverbs have no meaning but because they do, as metaphors and symbolic structures of meaning.

Local auteurs fill empty spaces by bridging them with hypotheticals. Extended chronologies are an ingenious concatenation device that reframes co-occurrences into lineality and myth into history. In the 1920s the famous Russian folklorist Vladimar Propp [31] said folktales have a narrative structure where functional elements follow a sequence. Applied to history, myths about the past are put into a narrative form, a coherent story. Terrell J in "Storytelling and Prehistory" [34] argues that scientific reports are similar to the structural outline Propp defines for folktales. The linear method of storytelling is an effective analogy for scientific communication. Narratives build "a sense of completeness...into accounts of history or prehistory (that) pull facts together into a coherent sense of cause and effect even when existing scientific theory is inadequate to account for the facts reported and inferences drawn."

The Ogiso chronology aligns pre-dynastic origins of Benin to a known historical dynasty. In the 1940s Chief Egharevba [35], the astute local historian, listed 11 Ogiso; by the time of his death the list had reached 30 and is climbing (so far: 34 ) as local historians strain to add names in an effort at symmetry. This symmetry would balance an Ogiso chronology against the 38 kings of the known record. It is a rhetorical, equivalence storytelling device, a structural method of narrative equation and balance. With the use of the internet this has become a fertile ground for a cottage industry of enthusiasts compelled to spawn storylines, with fry all over the web.

An irresistible temptation of history is the desire to install the corrective lens, to reconfigure events. Napoleon Bonaparte said that history is the version of past events that we have decided to agree upon. One of the most famous photographs of World War II by the Russian Yevgeny Khaldei, of soldiers hoisting the soviet flag over the burned-out Reichstag in Berlin, was staged. As Jonathan Turley of the Los Angeles Times tells us [36], "After seeing Associated Press photographer Joe Rosenthal's Iwo Jima picture, Khaldei tried to recreate a similar scene, shooting the soldiers from various poses. Since the battle was over, he added columns of smoke in the background. He removed wrist watches that appear on the arms of one of the soldiers, evidence of looting after the fall of Berlin."

But the Iwo Jima photograph that inspired this recreation is not what it seemed either. "The actual flag that was first raised was a relatively small one, hoisted by Marines on a piece of old pipe found on the island" Rosenthal later photographed a much larger flag that became the basis for a memorial consistent with the idea of Iwo Jima as a narrative image for posterity.

One recalls the three New York City firefighters raising the American flag on the smoking ruins of the World Trade Center, a spontaneous, gritty act. However, the photograph by Thomas E Franklin is politically incorrect. As Turley says, the memorial planned to commemorate that moment of patriotism requires cosmetic surgery. The flag is inspiring but two of the three white firefighters have to go. Ground zero demands racial equivalence. A Latino and African-American must be substituted. Turley says, "The gender and racial blindness that prevailed after the attacks apparently threatened some groups with obsolescence."

Anthropologists see cultures as assemblages or collages that emphasize continuous repositioning and contestable views, marked by disjunctions and contradictions. History, too, is an interpreted and negotiated process, not a simple arrangement of facts. Lukacs says that the internal order of history is neither a logical sequence, nor organized in accordance with historical facts. "Their sequence is rather determined by the relation they bear to one another... and which is the exact opposite of what seems to be their natural order or the order of their historical development."

Like the 9/11 Trade Towers and World War II events, Benin's history cannot be separated from its cultural moorings. History is not a literal interpretation. Some time ago the oba of Benin was summoned to court, an abomination. This got conflated with an event two years prior when market women bared their breasts to protest government decrees about market prices. These are compressed into the same event in support of the king.

Recognizing that history is an artifice, however, doesn't necessarily deny events, only that an objective analysis is problematic. The more obscure the record, the more distant in time, the more difficult is the reconstruction. We now have the skeleton of King Richard III, the last Plantagenet king slain at Bosworth Field in 1482, and so assailed as "the hunch-backed toad" by William Shakespeare. Yet in truth we know little about him, which leaves plenty of room for speculation: monstrous or beneficent? Tyrant or democrat? We interpret the evidence but know that archaeological remains are layered by sediment and sentiment. It's not facts so much as the glosses - the hypothetical assumptions, ideological inoculations, even poetic licenses and narrative shibboleths -- we put on them.

For Benin's pre-dynastic history, we are stuck with Don Quixote and the windmills. Don Quixote imagined the windmills were Dragons and Knights and he sets out to do battle with them while his sidekick, Sancho Panza, goes along with the illusion. Like the scholars of the prehistory of the Benin Kingdom, or local 
auteurs who fail to see the arbitrariness of their own creations, and professional historians who meld those creations into history, using folklore, charades, and Marxist theory to evolve imagination into an historical reality, and art historians who unwittingly accord baseline truth value to the Ogiso literary constructions, we are all Don Quixote tilting at windmills.

\section{References}

1. Bradbury RE (1959) The Social Structure of Benin with Special Reference to the Political-Ritual Organization. University of London, England.

2. Bradbury RE (1973) Benin Studies. Peter Morton-Williams, England.

3. Mark L (1981) Symbolic and Structural Archaeology, Cambridge University Press, India, pp. 179-184.

4. Lukacs G (1923) History and Class Consciousness: Studies in Marxist Dialectics, The Merlin Press, UK.

5. Tonkin E (1995) Narrating Our Pasts: The Social Construction of Oral History. Cambridge: Cambridge University Press, India.

6. Gramsci A (1971) Selections from the Prison Notebooks. In: Lawrence, Wishart, England.

7. Giddens A (1979) Central Problems in Social Theory, Macmillan Press, UK.

8. Goody J (2010) Myth, Ritual and the Oral. Cambridge: Cambridge University Press, India.

9. Bruner J (1993) Acts of Meaning: Four Lectures on Mind and Culture. Harvard University Press, USA.

10. Cohen A (1977) Two-Dimensional Man: An Essay on the Anthropology of Power and Symbolism in Complex Society. University of California Press, USA.

11. Vansina J (1984) Art History in Africa. Longmans, England.

12. Vansina J (1985) Oral Tradition as History. Madison: University of Wisconsin Press, USA.

13. Michel F, Sheridan A (1972) The Archaeology of Knowledge. New York: Pantheon Books, USA.

14. Bakhtin MM (1990) Art and Answerability: Early Philosophical Essays. Austin: University of Texas Press, USA.

15. Ian H (2012) Entangled: An Archaeology of the Relationship between Humans and Things. Wiley-Blackwell, USA.

16. David H (2009) Impossible to Disprove Yet Impossible to Believe: The Unforgiving Epistemology of Deep-Time Oral Tradition. History in Africa 36: 127-234.

17. Pierre B (1977) Outline of a Theory of Practice (Cambridge studies in Social and Cultural Anthropology16) Cambridge University Press, UK.

18. Omoregie OSB (1988) Benin Under the Ogiso Monarchy. Benin City: Nesaro Publishers, Nigeria.
19. Omoregie OSB (1997) Great Benin. Benin City: Neraso Publishers, Nigeria.

20. Uyilaiva U, Toyin F (1998) Comparison of JU Egharevba Ekhere Vbe Itan Edo and the Four Editions of 'A Short History of Benin.' History in Africa. A Journal of Method 25: 361-386.

21. Usuanlele Uyi, Toyin Falola (1994) The Scholarship of Jacob Egharevba of Benin. History in Africa 21: 303-318.

22. Omoregie SBO (1933-2015) Obituary. Umewaen: Journal of Benin and Edo Studies 1: 147-148.

23. Igbafe Philip (1974) Benin in the Pre-Colonial Era. Tarikh 5(1): 1-16.

24. Igbafe Philip (1979) Benin Under British Administration. The Impact of Colonial Rule on an African Kingdom 1897-1938. London: Longman.

25. Ryder Alan (1965) A Reconsideration of the Ife-Benin Relationship. Journal of African History 6(1): 25-37.

26. Ryder Alan Frederick Charles (1969) Benin and the Europeans 14851897. London: Longmans, UK.

27. Bonderanko D (2000) Pre-Imperial Benin: Formation and Evolution of the Socio-Political Institutions System. DSc Thesis Moscow Institute for African Studies p. 62.

28. Bonderanko D (2001) Pre-Imperial Benin: Formation and Evolution of the Socio-political Institutions Systems. Moscow: Institute for African Studies Press, Russia.

29. Bonderanko D (2004 ) Between the Ogiso and Oba Dynasties: An Interpretation of Interregnum in the Benin Kingdom. History in Africa 31: 103-115.

30. Bonderanko D (2006) Homoarchy: A Principle of Culture's Organization. The $13^{\text {th }}-19^{\text {th }}$ Centuries Benin Kingdom as a Non-State Super complex Society. DonKniga, Moscow.

31. Bonderanko D (2010) The Edo Pantheon and the Origin of the Institution of Supreme Ruler in Benin. In: [Eds.] NB Kochakova, VA Popov, Custom, Symbol, Power, Institute for African Studies, Moscow, pp. 316-323.

32. Peter R, Bonderanko D (2003) A Popular History of Benin. The Rise and Fall of a Mighty Forest Kingdom. Peter Lang publishing, Frankfurt am Main, New York, pp.391.

33. Everard J (1968) Vladimar Propp: Morphology of the Folktale. Austin: University of Texas Press, USA.

34. Terrell J (1990) Storytelling and Prehistory. In: [Eds.] MB Schiffer, Archeological Method and Theory, Cambridge: Cambridge University Press, UK, pp. 1-29.

35. Egharevba J (1968) A Short History of Benin [1936] (4 $4^{\text {th }}$ edn) Ibadan: Ibadan University Press, Nigeria.

36. Jonathan T (2002) Imposing Political Correctness on Ground Zero. The Los Angeles Times 18: B-15. 


\section{Your next submission with Juniper Publishers will reach you the below assets}

- Quality Editorial service

- Swift Peer Review

- Reprints availability

- E-prints Service

- Manuscript Podcast for convenient understanding

- Global attainment for your research

- Manuscript accessibility in different formats

( Pdf, E-pub, Full Text, Audio)

- Unceasing customer service

Track the below URL for one-step submission https://juniperpublishers.com/online-submission.php 